Journal of Southeast Asian

\title{
Because I am a Daughter: A Hmong Woman's Educational Journey
}

Kaozong Mouavangsou

University of California, Davis, kmouavangsou@ucdavis.edu

Follow this and additional works at: https://docs.lib.purdue.edu/jsaaea

Part of the Asian American Studies Commons, Education Commons, and the Feminist, Gender, and Sexuality Studies Commons

\section{Recommended Citation}

Mouavangsou, Kaozong (2018) "Because I am a Daughter: A Hmong Woman's Educational Journey," Journal of Southeast Asian American Education and Advancement. Vol. 13 : Iss. 1, Article 4.

DOI: $10.7771 / 2153-8999.1166$

Available at: https://docs.lib.purdue.edu/jsaaea/vol13/iss1/4

This document has been made available through Purdue e-Pubs, a service of the Purdue University Libraries. Please contact epubs@purdue.edu for additional information.

This is an Open Access journal. This means that it uses a funding model that does not charge readers or their institutions for access. Readers may freely read, download, copy, distribute, print, search, or link to the full texts of articles. This journal is covered under the CC BY-NC-ND license. 


\section{Because I am a Daughter: A Hmong Woman's Educational Journey}

\section{Cover Page Footnote}

This paper emerged from a Women's Feminist Studies graduate course that I took with Dr. Wendy Ho. I would like to thank her for assigning this assignment that gave me an opportunity me to critically reflect on my educational journey. I would also like to thank Dr. Julia Menard-Warwick, Dr. Karen Watson-Gegeo, Dr. Kieu-Linh Caroline Valverde, Dr. Wei Ming Dariotis, Julia Singleton, Vanessa Segundo, Caitlin Tienery, and Leefong Mouavangsou for their encouragement and feedback on earlier drafts of this paper. Lastly, I want to thank my mother, father, and brothers for sharing their wisdom of the Hmong culture and language with me so that I can have a deeper understanding of it. From the bottom of my heart, I thank you all. 


\title{
uSAAEA Journal of Southeast Asian American
Education and Advancement
}

Vol. 13 Iss. 1 (2018)

WWW.JSAAEA.org

\section{Creative and Literary Works}

\author{
Because I am a Daughter: \\ A Hmong Woman's Educational Journey
}

\author{
Kaozong N. Mouavangsou
}

University of California, Davis

\section{Introduction}

The story of how I came to acknowledge that my entire education was eurocentric in nature, and that I too accepted the fallacies in which such oppressive epistemologies framed Hmong culture and gender, is the journey I navigate as a scholar and daughter. "Stories" according to Alexander and Mohanty (2010) "are simultaneously 'maps' in that they mobilize both histories and geographies of power" (p. 475). In other words, stories are markers and mediums in which readers can physically locate the protagonist through time and space. Unlike "maps," stories invoke the emotions that maps cannot easily exert from individuals. Stories allow for people to hear for themselves the power structure that exists. Moreover, Adichie (2009) warns of the danger of listening to only one story and generalizing it. In my case, I generalized Hmong women as being oppressed by Hmong culture. However, it is important to reflect and understand that this narrative is one of many that perpetuates my Hmong community and influences the minds of Hmong women such as myself. I am all too familiar with these popular stories of oppression and patriarchy within Asian families. My story seeks to explore and understand how destructive this single story was in shaping how I negotiated the intersectionalities of my ethnic identity, culture, gender, and U.S. education.

\section{My Family}

I grew up in Fresno, California where I learned from my teachers that the United States of America is the land of opportunity where everyone is treated equal regardless of if you are a man or a woman. With this picture of America that was cultivated in my schooling, it was contradictory to, and created tensions with gendered expectations of my Hmong culture. In my eyes, the notion of

\footnotetext{
@)

SDREAIGHISRESEREEDReaders are free to copy, display, and distribute this article, as long as the work is attributed to the author(s) and the Journal of Southeast Asian American Education \& Advancement, it is distributed for non-commercial purposes only, and no alteration or transformation is made in the work. More details of this Creative Commons license are available at http://creativecommons.org/licenses/by-nc-nd/3.0/. All other uses must be approved by the author(s) or JSAAEA . Journal of Southeast Asian American Education \& Advancement, Vol. 13. Iss. 1. (2018) ISSN: 2153-8999
} 
"equality" created a dichotomy of Hmong and American culture. To me, America represented equality; an equality that I felt my Hmong culture did not possess.

Because my brothers are sons, they could go out with their friends.

Because I am a daughter, I could rarely go out with my friends.

Because my brothers are sons, they did not have to cook and clean much.

Because I am a daughter, I must.

Because my brothers are sons, people tell my parents they are lucky to have five of them.

Because I am a daughter, people tell my parents not to invest in me.

Because my brothers are sons, they will always be a part of the family.

Because I am a daughter, I will one day be considered a qhua (guest).

Because I am a daughter.

Because I am a daughter.

Simply because I am a daughter.

As a Hmong daughter pursuing an education, I often asked, "Where do I fit in? Can I even fit in? Wait, do I want to fit in?" As the second child and only daughter, I was fortunate enough to be born into a family that values education and have also gone to school in the United States. Both my parents and their families came to the United States as Hmong refugees who were uprooted from their home country of Laos. My father graduated with his bachelor's degree and my mother graduated with her high school diploma. My father has one sister who graduated with her high school diploma, two sisters with a bachelor's degree, one brother with a master's degree, and one sister who graduated with a doctorate degree. As for my mother's side, she has one brother who graduated with his high school diploma. As can be seen through the high levels of educational attainment in my family, they had already set a precedent of college education regardless of gender. My family also had high expectations for educational success, and navigational knowledge of the U.S. higher education system. However, it is also important to recognize that their educational achievements did not come easily. Upon their arrival, they did not know English, but maintained a strong foundation collectively in order to be where they are today.

At family gatherings, my relatives from my father's side would hold educational meetings where we as the children would sit around and hear them talk about the importance of education. Kuv puj (my paternal grandmother) would remind my cousins and I, "Kev kawm ntawv yog tus yuam sij uas qhib lub qhov rooj rau txoj kev vam meej" (Education is the key that will open the door to prosperity). Because my mother's side of the family did not hold as many degrees as my father's, kuv niam tais (my maternal grandmother), would remind me of their struggles in the United States because of their lack of education. She would say, "Rau siab kawm neb thiaj li tsis txom nyem li niam tais, dab luag, koj niam, thiab niam tais" (Work hard in school so you all won't have to suffer like your grandma, uncle, mom, and aunt). Both my grandmas emphasized the importance of education for the future of their children and grandchildren. Meanwhile, my relatives and parents would share with us what they know about our U.S. education and how to excel using resources such as our peers, friends, teachers, and mentors.

With the values of education instilled in me and being the only daughter in my family, I felt that education was my key to gender equality, in resistance to the male-dominated nature of Hmong culture. From elementary school to the beginning of graduate school, I had perceived my Hmong culture as male dominated because my experiences were framed solely by notions of gender as I learned them in school. Being born into a Hmong family, I understood early on that 
once I marry into my husband's family I would not be considered a part of my biological family. In Hmong, there is a famous paj lug (proverb) that says:

Cuaj lub hli tsis cuag ib lub nub, Cuaj leej ntxhais zoo tsis cuag ib leeg tub

(Nine moons can't compare to one sun,)

(Nine daughters can't compare to one son)

This paj lug represents the distinct values between Hmong daughters and sons, signifying once again the importance of sons compared to daughters. The comparison of the moons and the sun means that as daughters they may shine brightly but it is only the sun that can keep you warm. Sun provides the warmth and energy that the planets need; similarly sons provide that reassurance for parents that they will be taken care of later in life. Daughters, like the phases of the moon, come and go. They can bring light to their parents but they do not bring the stability that sons can. Given the responsibility between sons and daughters, it makes sense how and why such a proverb was created.

Furthermore, the values and privileges given to Hmong men is also seen in death. According to Hmong animism or ancestral worship, when a Hmong divorced woman dies her spirit cannot return to her parents since she is no longer part of their dab qhuas (house spirits). Similarly, her spirit cannot return to her ex-husband's dab qhuas either. Thus, her spirit dwells in the spirit world of the unknown ancestors, in other words, dab tu caj tu ces. However for Hmong men in death, they will always have a dab qhuas to go to even if they divorce their wives because they will always remain within their family.

Given that I come from a family that instills the importance of education and my desire to be seen as an equal compared to sons, it motivated me to excel in school. However, my prime motivator was my dual identity as a Hmong daughter and student. In Lee's study (1997) of Hmong women in higher education, her participants spoke "about the link between education and freedom from male domination" (p. 813). They believed "education leads to independence and selfempowerment" (Lee, 1997, p. 813). Similar to the women in Lee's study, education was my way of gaining that gender equality for which I had thirsted longingly. My hope was that once I become educated, I would be seen with respect similar to Hmong men, but little did I realize that there were certain expectations placed on me in terms of where I should and should not go for college.

Ever since I was in middle school, I had always shown kuv puj my report cards because I valued her judgment and wanted her to know I was doing well in school. When I received my college acceptance letters from Fresno state and two University of California (UC) campuses, UC Davis and UC Riverside, I told her. To my surprise, she encouraged me to attend Fresno State because it was closer to home. She referenced my aunts, who are her daughters as having successfully completed their bachelor's degree there. Additionally, she told me various stories about other Hmong daughters in our clan who went away for college. Based on her stories, I knew there was a stigma associated with our clan regarding daughters going off to college. Typically these stories ended with two scenarios, the daughters running to be with their boyfriends, coming back pregnant or pregnant and without a husband. All of these stories shared one common theme of them not completing their undergraduate degree. These are the stories that kuv puj told in order to discourage me from choosing a college away from home. The stories she selected demonstrated the consequences of not following the expectations of Hmong daughters, which is to always be close to home. 
Not only was I met with surprise by kuv puj's reaction, but also a few of my relatives as well. As I had mentioned earlier, my relatives are supporters of education and most had all graduated with at least their high school diploma. They know the difference between a UC and a state college, yet a few of them still discouraged me from going away for college. Their reasoning reverted back to Hmong culture, where I, as a daughter will not remain in the family. My education will not benefit my clan but my husband's because I will be joining his. I found it ironic that they preach educational equality for all but when it came to the fine details, they had a change of heart. A few even told my parents not to let me go to a UC because I am a daughter. Again, my parents were reminded that one day I will marry, and will leave my parents to help my in-laws. Their investment in my education would be expensive if I decide to go to a UC and it will not benefit them in the long run.

Knowing how my relatives felt, I was again oppressed with the fact that I will one day marry and not belong with my biological parents. In Hmong, when a woman marries her relatives tells her that:

Txij no mus ciaj los koj yog luag neeg, tuag los koj yog luag dab (From now on alive you are their people; dead you are their ghost)

This saying relates back to the Hmong culture (especially for those who believes in the traditional belief of animism) that when a Hmong woman marries she will join her husband's dab qhuas, therefore, in both life and death I have no ties to my parents. Furthermore, my parents have no real obligation to help me be successful in school because physically and spiritually I will not be with them. My relatives' view of education in accordance to my gender made me regret being born a daughter.

I remembered when my older brother, who is one year older than me got accepted to UC Riverside and none of my relatives mentioned any cultural expectations on to him or my parents. Their only comment was that it may be expensive. However in my situation, it was not just the cost but also the cultural expectations that they were imposing on my parents and me. I felt the weight of privileges between my brothers and I in the eyes of my relatives. I started to question why my relatives had encouraged me to get straight A's. I wondered why they held meetings with my cousins and I to talk about the importance of education and how to do well in school, if they also imposed these gendered expectations on us. Although it was only a few of my relatives that had expressed their views to my parents personally, they were the ones that had the largest impact on me. I looked up to them the most because of our close relationship and their passion towards educational equality and their accomplishments. Their views to discourage me from attending a UC made me realize that culture runs deep. Even in the land of opportunity in the year 2009, education is equal but only under certain circumstances.

Fortunately, my parents were supportive of me regardless of my gender and encouraged me to select the college I felt would allow me to reach my fullest potential. Thus, instead of following my older bother to UC Riverside, I chose to go to UC Davis. During my undergraduate, I did not have a job and was not able to support myself. My parents had also encouraged me to only focus on my schooling, while they paid for my living expenses. They would also drive every two weeks from Fresno to bring me food-just so that I have food to eat.

With the support of my parents, I was able to focus on my school and graduated from UC Davis in three years. Following my graduation, I immediately began my master's program and am now pursuing my doctorate. During my bachelor's graduation commencement, I realized that I had 
overcome the stigma that plagued my Moua clan and saw the change in reaction from kuv puj. Now, when someone asks her if she had supported me in going away for college, she tells them she did, when in truth she did not until I had completed my bachelor's. Similarly to kuv puj, my relatives who doubted and were not supportive of me have also told me how proud they are of me.

\section{Defining Culture and Gendered Ideologies}

Even though I grew up in a Hmong family and knew the customs, I was caught in the middle as an insider of my community by birthright but not knowledgeable enough to truly be considered in the deep parts of my culture. I only had the basic understanding of what it means to be a Hmong individual. I spoke Hmong language, ate Hmong food, and knew some of the cultural events, but not enough to be considered culturally deep. Watson-Gegeo and Gegeo (2004) define deep culture as "the heart of culture identity, cultural survival, and thinking. It includes ontology, cultural models, and indigenous epistemology" (p. 241). Deep culture required a reinterpretation of how I saw my Hmong culture, beyond the superficial and materials that I had listed. Based on their definition, I had internalized the westerner's perspective of my own culture. Truthfully, I saw my own culture as very oppressive and sexist because of male privileges that exist. I was caught in this web of understanding my culture through the lens of a westerner, where Hmong men are more privileged and are more valued, without trying to understand the reasons behind it. I had already imposed western views on my own culture without allowing room for me to make sense of them. Going deep into a culture takes more than simply being born into it, but a need to understand it.

My need to understand my own Hmong culture in the U.S. forced me to rethink what it meant to be Hmong. Feminist scholar, Uma Narayan (2004) warns about "attempting to balance the assertion of the value of a different culture or experience against the dangers of romanticizing it to the extent that the limitations and oppressions it confers on its subjects are ignored" (p. 214). I understand Narayan's concerns that I may dive too deep in my culture and be blinded to the oppression that exists. I have to maintain a firm balance between understanding the deep culture that Watson-Gegeo and Gegeo (2004) mentioned while simultaneously remembering to not romanticize it.

My hope in discussing my culture is to demonstrate the deep parts of culture that I was not aware of before. According to Eckert and McConnell-Ginet (2013), "Gender Ideology is the set of beliefs that govern people's participation in the gender order, and by which they explain and justify that participation" (p. 22). In other words, gender is a social construction that is based on the actions of individuals and how they perform that gender. Each action has specific reasons for why such expectations exist. Knowing that actions are tied to the culture adheres to Judith Butler's theory of performativity (1988). Butler argues that as human beings we are doing gender by performing the prescribed actions attributed to men and women.

\section{Hmong Culture}

For Hmong culture, gender ideological beliefs were largely influenced by strong familial and community values that take precedent over the self. Within Hmong's patrilineal clan system, the men carry on the family lineage, caaj ceg and the clan name, xeem (which are identified through the eighteen Hmong surnames), and therefore, have an obligation towards his family and clansmen 
(Hang, 1997; Yang, 1982; Mouavangsou, 2009). Once a Hmong woman marries, she will carry on her husband's caaj ceg and xeem, and her obligation is now directed towards her husband's family and clansmen.

In Hmong families that still practice animism or ancestral worship, each family is associated with dab qhuas that protects the family and must be respected (Cooper, 2008). When a daughter marries, her in-laws will do a formal ceremony to be a part of their dab qhuas, as opposed to sons who keep their same qab qhuas. Thus, sons play a vital role in not only the living but also the spirit realm. Specifically only households who have the same dab qhuas as the deceased can conduct the funeral, meaning that only sons are able to do funerals for their parents, not the daughters because daughters belong to a different dab qhuas (Cooper, 2008). The sons also continue the "worship of the parents and ancestors in the afterworld" (Yang, 1997, p. 3). Contextualizing lineage, beliefs, and responsibilities builds the foundation for understanding what the roles are in Hmong families. The exchange of responsibilities for one's birth parents and inlaws creates a system of balance within Hmong families when their sons and daughters marry; however, it also favors sons over daughters for the reasons above.

By understanding how gender functions within a Hmong family structure, we understand the gendered specified roles and expectations within a Hmong patriarchal system. Knowing how and why the world is the way it is. As Connell (1998) stated: "Gender is not only a system of meanings; it involves the material labor of housework and machine minding, the accumulation of wealth, the materialities of violence and power, pregnancy and child rearing, and so on" (p. 475). Based on Connell's definition, the prescribed roles for each gender revolves around the work they do both in the public and private world. Since Hmong men are the ones who stay within the clans, they are seen as the decision makers, although women can influence some decision-making ultimately, it is the men who have the final say. This may explain why Hmong men held positions of power within the clan, village, and the community at large as opposed to Hmong women. Hmong men are also required to help out the family and be the breadwinner who ventures out to provide food and shelter for their family. Women are responsible for household chores, childrearing and agricultural activities. Moreover, if that family believes in animism, then the men also must learn the customs and rituals that are needed for those religious ceremonies and rituals.

In a western perspective, the patriarchy that exists within Hmong culture oppresses women and does not adhere to the western view of equality. Denzi Kandiyoti (1988) explains there are different forms of patriarchy due to class, caste, and ethnicity and within these various patriarchy there is what she coins, patriarchy bargain. According to Kandiyoti (1988), "These patriarchal bargains exert a powerful influence on the shaping of women's gendered subjectivity and determine the nature of gender ideology in different contexts" (p. 275). Her usage of including bargain in naming the process implies that there is deal that is understood from both men and women who participate in this structure. Those who participate in the bargain are in a sense exerting their own agency. Kandiyoti (1988) describes this as women's "passive resistance takes the form of claiming their half of this particular bargain-protection in exchange for submissiveness and propriety" (p. 283). In the case of Hmong, Hmong women may passively bargain with the patriarchy for that protection that Kandiyoti talks about. My point here is through Kandiyoti, I realized patriarchy is not only an abstract structure but that in order for it to exists it involves people who are making it exist and those who follow it. This sense of understanding for one's own culture through non-western eyes is important. 


\section{My Epiphany}

Through my experience from high school to undergraduate, I realized I had wrongly positioned kuv puj and relatives as being unsupportive of my college education. Davies \& Harré's (1990) states that,

Positioning, as we will use it is the discursive process whereby selves are located in conversation as observably and subjectively coherent participants in jointly produced storylines. There can be interactive positioning in which what one positions another. And there can be reflexive positioning in which one positions oneself. However it would be a mistake to assume that, in either case, positioning is necessarily intentional. (p. 48)

Through retelling my story on paper, I realized I had interactively positioned both kuv puj and my relatives as supporters of the oppressive Hmong patriarchy where sons are privileged. I saw their reasoning as going against educational equality, the type that I was taught about in schools by western teachers.

For kuv puj, I had interactively position her as denying my ability to pursue a higher education. Without realizing and understanding her, I painted her as a bad person who exerted cultural expectations on me. Meanwhile, I reflexively saw myself as someone who was seeking her independence and education. It was only after I had completed my undergraduate that I saw the stance I was taking. I was imposing my U.S. and western mentality on kuv puj-I only saw her actions as furthering my oppression. I did not see that the stories she shared were her way of protecting me. Based on her observations and experiences with many of the women in my clan, going to Fresno state guaranteed their success of graduating as opposed to away from Fresno. It was not that she did not trust me but that she was afraid that if I were not close by she would not be able to protect and guide me in the same ways as if we were in the same city. According to Judith Butler (1988), my choice to go away for college went against the normativity choices of a Hmong daughter who is supposed to and should be close to home. I firmly do believe that I proved to kuv puj that my choice in attending UC Davis might seem to venture from the gender roles of Hmong women in Laos, but that in the United States that is acceptable. I also do believe that kuv puj now understands the expectations that were imposed then and now are different.

As for my relatives who had discouraged me, instead of condemning them like I had earlier, I was awakened. Similarly to kuv puj, I had interactively positioned my relatives as education oppressors who only want to invest in Hmong sons' education. Now, as I reflectively think about my situation then, I was wrong. I had assumed that based on my relatives' exposure to having lived in the United States for over 15 years, some having grown up here as children, and all of them having graduated with their high school diploma, would have wanted everyone to be equal. Although my relatives' experience may make them educated and American, they themselves are still negotiating their own identities as Hmong refugees or Hmong Americans living in the United States. They are still negotiating what is acceptable for Hmong sons and daughters, given what they know about our Hmong culture. For them, their educational bargain may be that daughters are able to go to school just like their sons and obtain a degree; however, it should be closer to home. Or perhaps that they rather all their children to attend school close to home regardless if they are a son or daughter. 


\section{Deception of an Educational Attainment}

Upon receiving my undergraduate degree, I also realized my naiveness in believing that education would be the key towards Hmong gendered equality. Even after having completed my bachelor's degree and being enrolled in the $\mathrm{PhD}$ program, I am not seen as an equal among Hmong men. Although Uma Narayan (2004) had previously warned about romanticizing culture, I am stating here that I romanticized the U.S. education system. My teachers and Hmong community led me to believe that education would be my freedom. It was not until I had already graduated with my bachelor's degree and was partially through my Ph.D. that I understood this-education is not my liberation. Simply having an education does not mean I am liberated. I began questioning why I had negative views about my community and where did I even learn it? How did I have the words to name my experience as "not equal" and "not fair?" From whose definition of "equal" and "fair" was I referring to? That was when I realized that my education, although it has its benefits, blinded me from recognizing how it was shaping the way I think about my community and culture, and even how I interpret what I thought I knew. My educational experience gave me a deficit understanding of what it means to be a Hmong daughter growing up in the United States. I only knew half the truth. I only had my western lens. I had forgotten my Hmong lens. I had placed a higher value on my western views, believing them to be more progressive and fair, while placing Hmong culture and community as static and never changing. This was where I went wrong.

In Lee's research (1997) on Hmong women in higher education, she concluded that Hmong culture is changing and that "cultural transformation is not a smooth process, but a fraught with tension and struggle" (p. 285). I do agree with Lee that cultural transformation has taken place similarly like with education, but at the same time there is an importance to understand one's culture deeply without diminishing it. Understanding the culture, recognizing its realities, and acknowledging that cultures are fluid will provide a space for understanding the ever-changing expectations of my community. I firmly believe that if I had this perspective of my culture as a senior in high school, I would have understood the underlying message that kuv puj and relatives'

were trying to convey. Those many years of bitterness and misunderstanding would never have taken place. However, I do recognize that not everyone comes to this realization in their lifetime. Some will always perceive the Hmong culture as oppressive. Some will say, "You know how Hmong people are" to create a generalization that once again, Hmong people who are a part of the Hmong culture are oppressing women. This perspective again does not acknowledge and denies the fact that culture is never truly static. Culture is fluid.

\section{Final Thoughts}

The truth is even after reflecting back on my educational journey; I am still not certain what my future will look like as a Hmong American woman. In many years to come, my identity will change and I will be a Hmong American wife, mother, daughter-in-law, sister-in-law, aunt, grandmotherall of which I cannot truly know for certain how and what I will be like. Even after I have sorted out and understood that my changed perspective on how I initially saw my community created a bridge between my grandmother and I, I am still stuck between these two worlds. I wonder what other issues will I come into conflict with as I continue on being alive. I think about how much the 
Hmong cultural roles will have on me if I become a professor at a research university? Will I have time to watch over my children? Will I be able to take care of my in-laws?

Although I cannot predict for certain the conflicts that will arise in my future, I am already expecting some. I am curious to know that even after I have gone through this revitalization of reconstructing how I was educated to re-see the world, if I will still have to continue doing that for the rest of my life. I will admit, I do worry about my future family. Like Kandiyoti (1988), I am already anticipating the bargain that will happen in my own family.

My purpose in sharing my personal stories was to show the layers of complexity that can exists within Hmong families and the community at large. Furthermore, it was to demonstrate the misconceptions of Hmong culture and how my westerner views taught to me by my educational schoolings have shaped the ways I understood my world. Although my experience is only one of many, it does demonstrate how much my educational schoolings influenced my negotiation between the Hmong and American world. It can be complicated and messy at times because they do not align perfectly with each other. I believe that in order to foster a better understanding between the trans-generational Hmong American students and their Hmong family, it is imperative to recognize the differences and know how to navigate through these spaces. Similarly, I hope that this bridge of understanding can also transfer over into the U.S. public and create a space for diversity within academia and beyond, not just for Hmong communities, but for communities of other cultures and backgrounds.

\section{Acknowledgement}

This paper emerged from a Women's Feminist Studies graduate course that I took with Dr. Wendy Ho. I would like to thank her for assigning this assignment that gave me an opportunity to critically reflect on my educational journey. I would also like to thank Dr. Julia Menard-Warwick, Dr. Karen Watson-Gegeo, Dr. Kieu-Linh Caroline Valverde, Dr. Wei Ming Dariotis, Julia Singleton, Vanessa Segundo, Caitlin Tienery, Leefong Mouavangsou, and the JSAAA collective and its reviewers for their encouragement and feedback on earlier drafts of this paper. Lastly, I want to thank my mother, father, and brothers for sharing their wisdom of the Hmong culture and language with me so that I can have a deeper understanding of it. From the bottom of my heart, I thank you all.

\section{References}

Alexander, M., \& Mohanty, C. (2010). Cartographies of knowledge and power: Transnational feminism as radical praxis. In A. Swarr \& R. Nagar (Eds.). Critical transnational feminist praxis (pp. 23-45). New York, NY: SUNY Press.

Adichie, C. (2009). The danger of a single story. Retrieved from http://b.3cdn.net/ascend/2029fab7aa68da3f31_jqm6bn6lz.pdf

Butler, J. (2013). Performative acts and gender constitution: An essay in phenomenology and feminist theory. In C. R. McCann (Ed.), Feminist theory reader: Local and global perspectives (pp. 462-473). New York, NY: Routledge. 
Cha, D. (1996). Dia's story cloth. New York, NY: Lee \& Low Books.

Chan, S. (1994). Hmong means free: Life in Laos and America. Philadelphia, PA: Temple University Press.

Connell, R. (1998). R. W. Connell's masculinities: Reply. Gender and Society, 12(4), 474-477.

Cooper, R. G. (2008). The Hmong: A guide to traditional life (vanishing cultures of the world). New York, NY: Marshall Cavendish International.

Eckert, P., \& McConnell-Ginet, S. (2013). Language and gender. Cambridge, UK: Cambridge University Press.

Hillmer, P. (2010). A people's history of the Hmong. Minnesota, MN: Minnesota Historical Society Press.

Kandiyoti, D. (1988) Bargaining with patriarchy. Gender and Society, 2(3), 274-290.

Lee, M. N. M. (1998). The thousand-year myth: Construction and characterization of Hmong. Hmong Studies Journal, 2(2), 1-23.

Lee, S. (1997). The road to college: Hmong American women's pursuit of higher education. Harvard Educational Review, 67(4), 803-828.

Mouavangsou, C. (2009). Traditional Hmong marriage ceremony values and practices: Influence and change as a result of immigration. (Unpublished doctoral dissertation). Alliant International University, Fresno.

Narayan, U. (2004). The project of feminist epistemology: Perspectives from a nonwestern feminist. The feminist standpoint theory reader: Intellectual and political controversies, 213-224. New York, NY: Routledge.

Watson-Gegeo, K. A., \& Gegeo, D. W. (2004). Deep culture: Pushing the epistemological boundaries of multicultural education. In G. Goodman \& K. Carey (Eds.), Critical multicultural conversations, (pp. 235-256). Cresskill, NJ: Hampton Press.

Yang, D. (1982). Why did the Hmong leave Laos? In B. T. Downing \& D.P. Olney (Eds.). The Hmong in the West: Observations and reports. (pp. 3-18). Minneapolis, MN: Center for Urban and Regional Affairs, University of Minnesota.

Yang, K. (1997). Hmong men's adaptation to life in the United States. Hmong Studies Journal, 1(2), 1-22.

Yang, K. (2012). Commentary: Mis-education in K-12 teaching about Hmong culture, identity, history and religion. Hmong Studies Journal, 13(1), 1. 


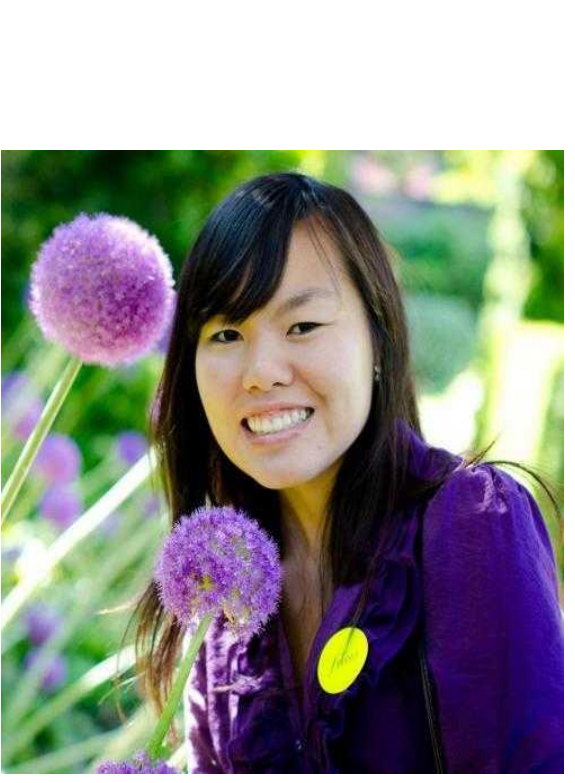

\section{About the Author}

Kaozong N. Mouavangsou is a PhD Candidate at the School of Education, University of California, Davis in the emphasis area of Language, Literacy, and Culture, and a designated emphasis on Feminist Theory and Research. She also received her Maser of Arts in Education and Bachelor's of Arts in English with a double minor in Education and Asian American Studies from the University of California, Davis. She has worked with various campus communities serving both undergraduate and graduate students through student organizations, initiatives, and in her role as a Teaching Assistant and Associate Instructor in Asian American Studies and the School of Education. In the summer of 2015, she developed and taught the first Hmong American Experience course offered at UC Davis. Mouavangsou's area of research focuses on the educational experiences of Hmong American students, higher education, and gender. 


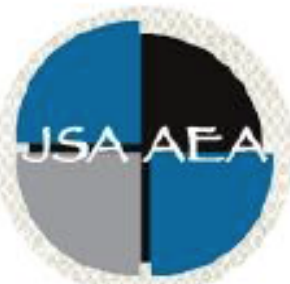

Vol.13 Iss.1 (2018)

\section{Journal of Southeast Asian American Education and Advancement}

\author{
Editor \\ Dr. Wayne E. Wright \\ Purdue University \\ Associate Editors \\ Dr. Chhany Sak-Humphry \\ University of Hawaii at Manoa \\ Dr. Phitsamay Sychitkokhong Uy \\ University of Massachusetts, Lowell \\ Book Review Editor \\ Dr. Vichet Chhuon \\ University of Minnesota \\ Creative Works Editor \\ Bryan Thao Worra \\ Lao Assistance Center \\ Journal Manager \\ Fang Gao \\ Purdue University
}

Editorial Review Board

\author{
Dr. Steve Arounsack \\ California State University, Stanislaus \\ Dr. Sovicheth Boun \\ Salem State University \\ Dr. Virak Chan \\ Purdue University \\ Dr. Loan Dao \\ University of Massachusetts Boston
}

\author{
Dr. Carl L. Bankston III \\ Tulane University \\ Dr. Phala Chea \\ Lowell Public Schools \\ Dr. George Chigas \\ University of Massachusetts, Lowell \\ Dr. Hien Duc Do \\ San Jose State University
}


Dr. Changming Duan

University of Missouri-Kansas City

Dr. Sothy Eng

Lehigh University

Dr. Vincent K. Her

University of Wisconsin, Eau Claire

Dr. Peter Nien-Chu Kiang

University of Massachusetts, Boston

Dr. Kevin K. Kumashiro

University of Illinois, Chicago

Dr. Ha Lam

Eastern Mennonite University

Dr. Jonathan H. X. Lee

San Francisco State University

Dr. Monirith Ly

Royal University of Phnom Penh

Dr. Bic Ngo

University of Minnesota

Dr. Leakhena Nou

California State University, Long Beach

Dr. Mark Pfeifer

SUNY Institute of Technology

Dr. Loan T. Phan

University of New Hampshire

Dr. Karen Quintiliani

California State University, Long Beach

Dr. Angela Reyes

Hunter College

The City University of New York

Dr. Fay Shin

California State University, Long Beach

Dr. Christine Su

College of San Mateo

Dr. Alisia Tran

Arizona State University

Dr. Khatharya Um

University of California, Berkeley

Dr. Kim Tran

University of California, Los Angeles,

Glendale Community College

Dr. Molly Wiebie

The University of Texas at Austin
Dr. Sophal Ear

Occidental College

Dr. Jeremy Hein

University of Wisconsin, Eau Claire

Dr. Nancy H. Hornberger

University of Pennsylvania

Dr. Peter Tan Keo

New York University

Dr. Yvonne Kwan

San Jose State University

Dr. Ravy Lao

California State University, Los Angeles

Dr. Stacey Lee

University of Wisconsin, Madison

Dr. Sue Needham

California State University, Dominguez Hills

Dr. Max Niedzwiecki

Daylight Consulting Group

Dr. Clara Park

California State University, Northridge

Dr. Giang Pham

University of Massachusetts Amherst

Dr. Malaphone Phommasa

University of Clifornia Santa Barbara

Dr. Kalyani Rai

University of Wisconsin-Milwaukee

Dr. Cathy J. Schlund-Vials

University of Connecticut, Storrs

Dr. Nancy J. Smith-Hefner

Boston University

Dr. Yer J. Thao

Portland State University

Dr. Monica M. Trieu

Purdue University

Dr. Silvy Un

Saint Paul Public Schools

Dr. Linda Trinh Vo

University of California, Irvine

Dr. Yang Sao Xiong

The University of Wisconsin-Madison

Dr. Zha Blong Xiong

University of Minnesota 


\section{Doctoral Student Editorial Review Board}

\author{
Linh Dang \\ University of Rochester \\ My-Lan Huynh \\ California State University East Bay \\ Hoa Nha Nguyen \\ Boston College \\ Thien-Huong Ninh \\ University of Southern California \\ Krissyvan Truong \\ Claremont Graduate University \\ Melissa Vang \\ San Diego State University \\ Claremont Graduate University \\ Anna H. Yang \\ University of Georgia
}

\author{
Annie BichLoan Duong \\ San Joaquin County Office of Education \\ Dung Minh Mao \\ University of Minnesota \\ Khoi Nguyen \\ George Mason University \\ Linda Marie Pheng \\ University of Wisconsin-Madison \\ Mai Vang \\ University of Massachusetts Boston \\ Soua Xiong \\ San Diego State University \\ Claremont Graduate University
}

